\title{
Data report: permeability measurements under confining pressure, Expeditions 315 and 316, Nankai Trough' ${ }^{1}$
}

\author{
Thierry Reuschle ${ }^{2}$
}

\section{Chapter contents}

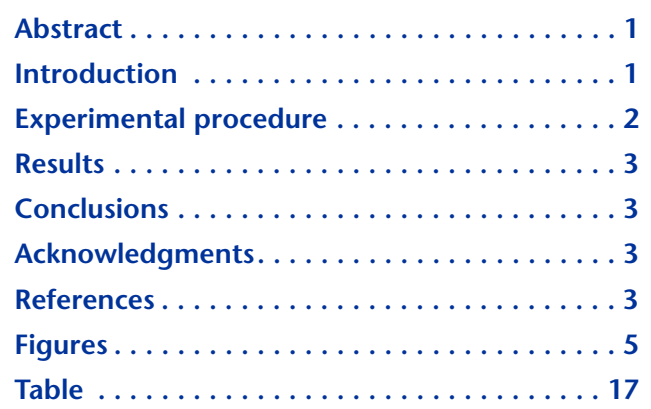

${ }^{1}$ Reuschle, T., 2011. Data report: permeability measurements under confining pressure, Expeditions 315 and 316, Nankai Trough. In Kinoshita, M., Tobin, H., Ashi, J., Kimura, G., Lallemant, S., Screaton, E.J., Curewitz, D., Masago, H., Moe, K.T., and the Expedition 314/315/316 Scientists, Proc. IODP, 314/315/316: Washington, DC (Integrated Ocean Drilling Program Management International, Inc.). doi:10.2204/iodp.proc.314315316.205.2011 2Ecole et Observatoire des Sciences de la TerreInstitut de Physique du Globe de Strasbourg, 5 Rue René Descartes, 67084 Strasbourg Cedex, France. thierry.reuschle@unistra.fr

\begin{abstract}
Permeability of six samples from Integrated Ocean Drilling Program (IODP) Sites C0001 and C0006 was measured in a triaxial cell under effective hydrostatic confining pressure from 1 to 30 $\mathrm{MPa}$. Sample depths range from 225 to 448 meters below seafloor (mbsf) for Site C0001 and from 201 to 564 mbsf for Site C0006. Our results indicate that the initial permeability at $1 \mathrm{MPa}$ of effective confining pressure ranges from $4.6 \times 10^{-18}$ to $1.8 \times 10^{-19} \mathrm{~m}^{2}$ depending on depth. Permeability decreases with increasing depth, which also corresponds to a decrease of porosity from $62 \%$ to $43 \%$. The permeability versus depth trend is similar for both sites. When the effective confining pressure is increased from 1 to $30 \mathrm{MPa}$, the permeability decreases for all samples. However, this trend shows some variability, indicating a finer microstructural control depending on the lithologic origin of the sample.
\end{abstract}

\section{Introduction}

When analyzing deformation processes in accretionary complexes like Nankai, one has to take into account several timescales. One important timescale is a result of the competition between two kinetics, one related to the eventual pore pressure build-up linked to pore fluid trapping during tectonic loading of the subduction zone and the other related to the ability of the pore fluid to flow out of the system, thus leading to pore pressure dissipation and avoiding any effective confining stress decrease that would enhance unstable slip of the system. The fluid flow is controlled by the hydraulic diffusivity of the rock, a function of both permeability and specific storage. Permeability measurements on samples from the Nankai accretionary complex have been previously performed without pressure confinement (Taylor and Fisher, 1993) or at low confining pressure $(<1 \mathrm{MPa})$ (Gamage and Screaton, 2003; Karig, 1993). Measurements of permeability at effective confining pressure of $1-5 \mathrm{MPa}$ give lower values (Byrne et al., 1993). More recently, Bourlange et al. (2004) reported permeability measurements on three samples from Ocean Drilling Program Leg 190 performed in the 0.2-2.5 MPa range in a triaxial cell with the main purpose of approaching in situ stress conditions. Overall, their results indicate that permeability decreases from $10^{-18}$ to $10^{-19} \mathrm{~m}^{2}$ with effective confining pressure increasing from 0.2 to $1.5 \mathrm{MPa}$. When the effective pressure is then 
increased from 1.5 to $2.5 \mathrm{MPa}$, permeability is roughly constant $\left(\sim 1 \times 10^{-19}\right.$ to $\left.4 \times 10^{-19} \mathrm{~m}^{2}\right)$, indicating a threshold pressure beyond which fracture closure is stopped. However, measurements at low effective pressure were too dispersed to yield a precise general relationship between pressure and permeability, and thus crack geometrical parameters.

In this report, we present permeability measurements performed at $1-30 \mathrm{MPa}$ in a hydrostatic cell with the main goal of refining this relationship, thus giving some new insights in the pressure dependence of microstructural characteristics of samples having various lithologic origins.

\section{Experimental procedure}

Permeability measurements were performed on two sets of samples from Sites C0001 (Expedition 315) and C0006 (Expedition 316) at various depths (Fig. F1). For each depth level, two cylindrical specimens (20 $\mathrm{mm}$ in diameter and $15-20 \mathrm{~mm}$ in length) were drilled out of the initial cores in a vertical direction (Fig. F2), one for porosity determination and the other for permeability measurement. The porosity of the unstressed samples was measured by using the triple-weighing method: successive measurements of the preserved originally saturated, saturated immersed, and dry specimen masses lead to the determination of the connected porosity. Table T1 summarizes porosity data for the tested samples and Figure F3 illustrates the porosity depth dependence. This dependency compares well with porosity data obtained onboard and derived from resistivity logs (see the "Expedition 315 Site C0001" [Expedition 315 Scientists, 2009] and "Expedition 316 Site C0006" [Expedition 316 Scientists, 2009] chapters).

Permeability measurements were carried out at room temperature in a $200 \mathrm{MPa}$ hydrostatic pressure cell equipped with a pore fluid pressure circuit (Fig. F4). The entire apparatus was thermally regulated to keep pressures constant in the absence of imposed pressure changes. The samples were isolated from the confining pressure fluid by a Viton jacket clamped on the end pieces connected to the pore fluid circuit. Pore fluid and confining pressures $\left(P_{\mathrm{P}}\right.$ and $P_{\mathrm{C}}$, respectively) were controlled separately. During the experiments, an effective pressure $\left(P_{\mathrm{C}}-P_{\mathrm{P}}\right)$ of at least $1 \mathrm{MPa}$ was maintained on the sample to ensure uniform contact of the jacket with the specimen and to avoid any leaking. All the experiments were run on samples preserved with their original pore fluids and in a saturated state.

The initial pressure conditions for all samples were $P_{\mathrm{C}}=3 \mathrm{MPa}$ and $P_{\mathrm{P}}=2 \mathrm{MPa}$ in order to be able to com- pare their hydraulic conductivities. Once the pressures were constant, permeabilities were measured using a pulse decay method (Bernabé, 1987; Brace, 1984). After closing the isolating valve between the upstream and downstream pore pressure circuits, a small step change of differential pore fluid pressure $\Delta P_{\mathrm{p}}=P_{\text {up }}-P_{\text {down }}$ was imposed in the upstream pore pressure section. Both pressures were then free to return to equilibrium through the sample. When the compressive storage in the sample is much smaller than the compressive storage in the pore fluid circuits, the differential pore pressure decay $\Delta P_{\mathrm{P}}$ is approximately exponential and the decay time is inversely proportional to the permeability, as shown by the following equations (Hsieh et al., 1981):

$$
\Delta P_{\mathrm{P}}(t) \propto \exp (-\alpha t)
$$

and

$$
\alpha=\left[A k\left(C_{\mathrm{u}}+C_{\mathrm{d}}\right)\right] /\left(\mu L C_{\mathrm{u}} C_{\mathrm{d}}\right),
$$

where

$$
\begin{aligned}
t= & \text { time } \\
A & =\text { section area } \\
L & =\text { sample length } \\
\mu & =\text { pore fluid viscosity }\left(10^{-3} \mathrm{~Pa} \cdot \mathrm{s} \text { at } 20^{\circ} \mathrm{C}\right), \\
k= & \text { permeability, } \\
C_{\mathrm{u}}= & \text { compressive storage of the upstream pore } \\
& \text { pressure circuit, and } \\
C_{\mathrm{d}}= & \text { compressive storage of the downstream pore } \\
& \text { pressure circuit. }
\end{aligned}
$$

$C_{\mathrm{u}}$ and $C_{\mathrm{d}}$ are defined as the ratios of the change of fluid volume to the corresponding pore pressure variation $\left(C=\delta V / \delta P_{\mathrm{p}}\right)$, which are physical constants of the apparatus and have been experimentally determined as $C_{\mathrm{u}}=3.957 \times 10^{-9} \mathrm{~m}^{3} / \mathrm{MPa}$ and $C_{\mathrm{d}}=$ $4.828 \times 10^{-9} \mathrm{~m}^{3} / \mathrm{MPa}$. For large timescales, Hsieh et al. (1981) have shown that the pore pressure decay with time has a form similar to Equation 1. This similarity is due to the fact that at large timescales the effect of storativity in the sample itself becomes negligible. In Figure F5 we show an example of pore pressure evolution with time (Fig. F5A) and the resulting differential pore pressure decay (Fig. F5B). As one can see, a single exponential law fits the data well over the entire experimental time span, indicating that neglecting the storativity in the sample may be a valid assumption. The permeability value is then deduced from the slope of the exponential fitting curve by using Equation 2 .

This measurement method was used for all samples at increasing levels of effective confining pressure $\left(P_{\mathrm{C}}\right.$ $-P_{\mathrm{p}}$ ) from 3 to $30 \mathrm{MPa}$, with $2 \mathrm{MPa}$ increase steps for $P_{\mathrm{C}}$ and a constant $P_{\mathrm{P}}$ of $2 \mathrm{MPa}$. Because the pulse de- 
cay method requires a small initial pore pressure difference $(10 \%)$ compared to the equilibrium pore pressure, we applied an initial $0.5 \mathrm{MPa}$ positive pulse to the upstream pore circuit, but we restricted our analysis to the final $0.2 \mathrm{MPa}$ portion of the $\Delta P_{\mathrm{P}}$ decay curve.

\section{Results}

Permeability measurements were performed on samples referenced in Table T1 using the procedure described above. A complete series of measurements on one sample, including equilibration times between permeability measurements, lasted $\sim 2$ months. In Figure F6, we plotted permeability data at the initial pressure conditions $\left(P_{\mathrm{C}}=3 \mathrm{MPa}\right.$ and $\left.P_{\mathrm{P}}=2 \mathrm{MPa}\right)$ as a function of depth for both sites. This diagram gives us a good insight into the permeability versus depth trend, permeability decreases as depth increases and the trend is similar for both sites. Moreover, the permeability at Site C0006 is lower than the permeability at Site C0001 for equivalent depths. This point is easily explained by the lower porosity encountered at Site C0006. Figure F7 illustrates the good correlation between porosity (unstressed state) and permeability at the initial pressure conditions for all samples. The permeability trend with depth observed at Site C0001 is consistent with data obtained by Likos et al. (submitted). Our measurements are, however, lower than their data, a difference that can be explained by the lower effective stress $(0.55 \mathrm{MPa})$ applied to the samples by Likos et al. (submitted).

Indeed, our measurements indicate a permeability decrease more than 1.5 orders of magnitude when an increasing effective confining pressure up to $30 \mathrm{MPa}$ is applied. Figure F8 summarizes the obtained data for Sites C0001 and C0006. As one can see, the decrease of permeability is apparent for all samples, but the shape of the curve differs from one sample to the other, reflecting variability in their microstructural content.

\section{Conclusions}

Permeability measurements were performed on samples from Sites C0001 and C0006 in a triaxial cell under effective hydrostatic confining pressure ranging from 1 to $30 \mathrm{MPa}$. The pulse decay method was employed and showed an exponential trend of the differential pore pressure with time, allowing the calculation of well-constrained permeability data. A decrease of the initial permeability at $1 \mathrm{MPa}$ effective pressure from $4.6 \times 10^{-18}$ to $1.8 \times 10^{-19} \mathrm{~m}^{2}$ with increasing depth was observed at both sites and is well correlated with the porosity trend. When the effective confining pressure is increased from 1 to 30 $\mathrm{MPa}$, the permeability decreases for all samples. However this trend shows some variability, indicating a finer microstructural control depending on the lithological origin of the sample.

\section{Acknowledgments}

We acknowledge the constructive remarks of L. Screaton and an anonymous reviewer. Samples and/or data were provided by the Integrated Ocean Drilling Program (IODP). We would like to thank P. Henry (Site C0001) and L. Louis (Site C0006) for supplying the samples. We also thank J.-D. Bernard for technical advice during the test period.

\section{References}

Bernabé, Y., 1987. A wide range permeameter for use in rock physics. Int. J. Rock. Mech. Min. Sci. Geomech. Abstr., 24(5):309-315. doi:10.1016/0148-9062(87)90867-9

Bourlange, S., Jouniaux, L., and Henry, P., 2004. Data report: permeability, compressibility, and friction coefficient measurements under confining pressure and strain, Leg 190, Nankai Trough. In Mikada, H., Moore, G.F., Taira, A., Becker, K., Moore, J.C., and Klaus, A. (Eds.), Proc. ODP, Sci. Results, 190/196: College Station, Texas (Ocean Drilling Program), 1-16. doi:10.2973/ odp.proc.sr.190196.215.2004

Brace, W.F., 1984. Permeability of crystalline rocks: new in situ measurements. J. Geophys. Res., [Solid Earth], 89(B6):4327-4330. doi:10.1029/JB089iB06p04327

Byrne, T., Maltman, A., Stephenson, E., Soh, W., and Knipe, R., 1993. Deformation structures and fluid flow in the toe region of the Nankai accretionary prism. In Hill, I.A., Taira, A., Firth, J.V., et al., Proc. ODP, Sci. Results, 131: College Station, TX (Ocean Drilling Program), 83-101. doi:10.2973/odp.proc.sr.131.107.1993

Expedition 315 Scientists, 2009. Expedition 315 Site C0001. In Kinoshita, M., Tobin, H., Ashi, J., Kimura, G., Lallemant, S., Screaton, E.J., Curewitz, D., Masago, H., Moe, K.T., and the Expedition 314/315/316 Scientists, Proc. IODP, 314/315/316: Washington, DC (Integrated Ocean Drilling Program Management International, Inc.). doi:10.2204/iodp.proc.314315316.123.2009

Expedition 316 Scientists, 2009. Expedition 316 Site C0006. In Kinoshita, M., Tobin, H., Ashi, J., Kimura, G., Lallemant, S., Screaton, E.J., Curewitz, D., Masago, H., Moe, K.T., and the Expedition 314/315/316 Scientists, Proc. IODP, 314/315/316: Washington, DC (Integrated Ocean Drilling Program Management International, Inc.). doi:10.2204/iodp.proc.314315316.134.2009

Gamage, K., and Screaton, E., 2003. Data report: permeabilities of Nankai accretionary prism sediments. In Mikada, H., Moore, G.F., Taira, A., Becker, K., Moore, J.C., and Klaus, A. (Eds.), Proc. ODP, Sci. Results, 190/196: 
College Station, TX (Ocean Drilling Program), 1-22. doi:10.2973/odp.proc.sr.190196.213.2003

Hsieh, P.A., Tracy, J.V., Neuzil, C.E., Bredehoeft, J.D., and Silliman, S.E., 1981. A transient laboratory method for determining the hydraulic properties of "tight" rocksI. Theory. Int. J. Rock. Mech. Min. Sci. Geomech. Abstr., 18(3):245-252. doi:10.1016/0148-9062(81)90979-7

Karig, D.E., 1983. Reconsolidation tests and sonic velocity measurements of clay-rich sediments from the Nankai Trough. In Hill, I.A., Taira, A., Firth, J.V., et al., Proc. ODP, Sci. Results, 131: College Station, TX (Ocean Drilling Program), 247-260. doi:10.2973/ odp.proc.sr.131.127.1993
Likos, W.J., Yue, L., Guo, J., and Underwood, M., submitted. Laboratory permeability characteristics: Site C0001. Geochem., Geophys., Geosyst.

Taylor, E., and Fisher, A., 1993. Sediment permeability at the Nankai accretionary prism, Site 808. In Hill, I.A., Taira, A., Firth, J.V., et al., Proc. ODP, Sci. Results, 131: College Station, TX (Ocean Drilling Program), 235-245. doi:10.2973/odp.proc.sr.131.131.1993

Initial receipt: 5 October 2010

Acceptance: 12 July 2011

Publication: 29 September 2011

MS 314315316-205 
Figure F1. Lithostratigraphy and location of samples. A. Site C0001. (Continued on next page.)

A

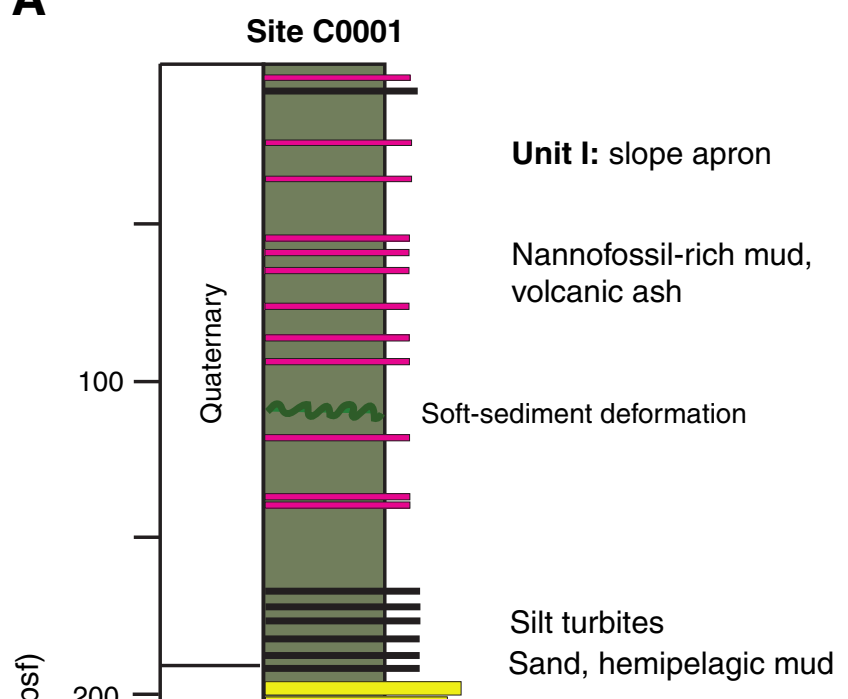

Sand, hemipelagic mud

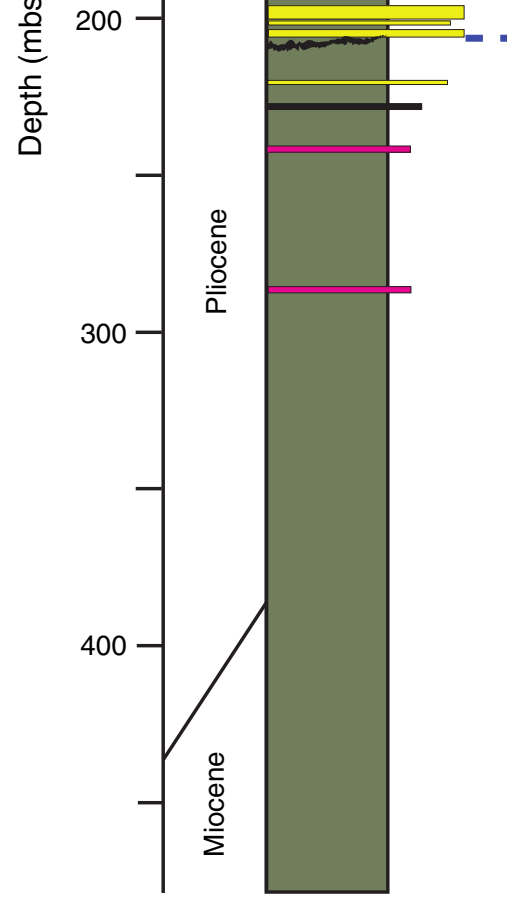

Bioturbated hemipelagic mud

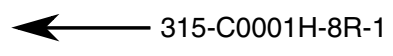
depleted in biogenic carbonate, rare silt, and volcanic ash

Interpretation: outer marginal trench facies?
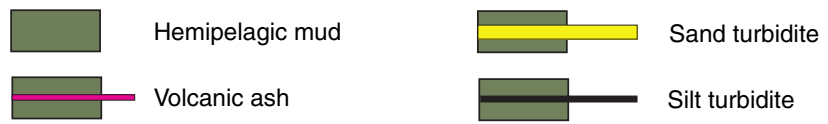
Figure F1 (continued). B. Site C0006.

B

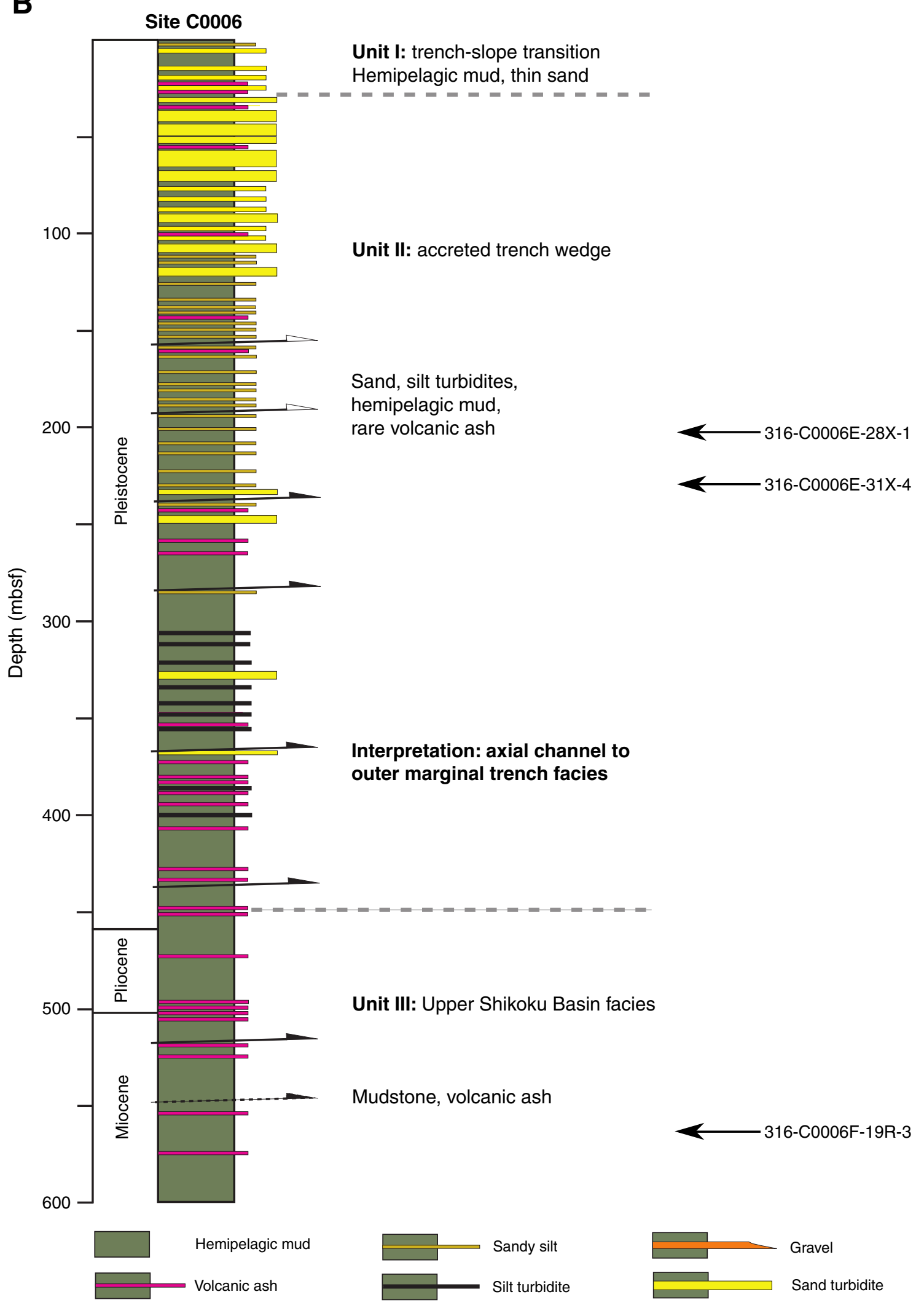


Figure F2. Photograph of sample before permeability measurements (Section 315-C0001F-18H-6).

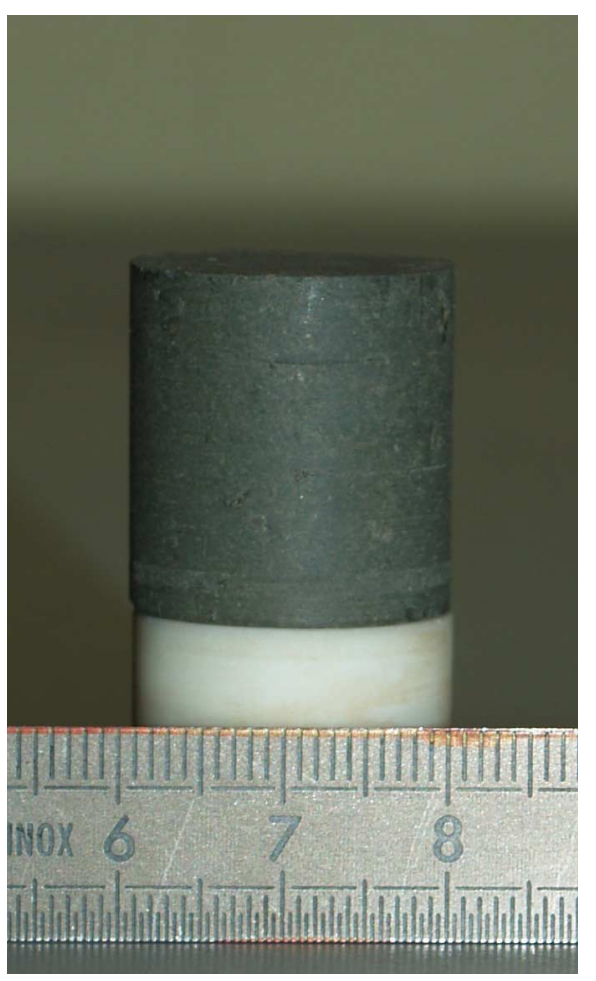


Figure F3. Porosity versus depth diagram for tested samples (open circles = porosity data obtained by tripleweighing technique applied on the preserved, originally saturated samples) superimposed on shipboard porosity-depth data for Sites C0001 and C0006 (see the "Expedition 315 Site C0001" [Expedition 315 Scientists, 2009] and "Expedition 316 Site C0006" [Expedition 316 Scientists, 2009] chapters for more details). A. Bit resistivity-derived porosity using Archie's law with parameters $a=1$ and $m=2.4$ compared with porosity derived from image-derived porosity (IDRO) and thermal neutron porosity (TNPH) in Hole C0001D. (Continued on next page.)

A

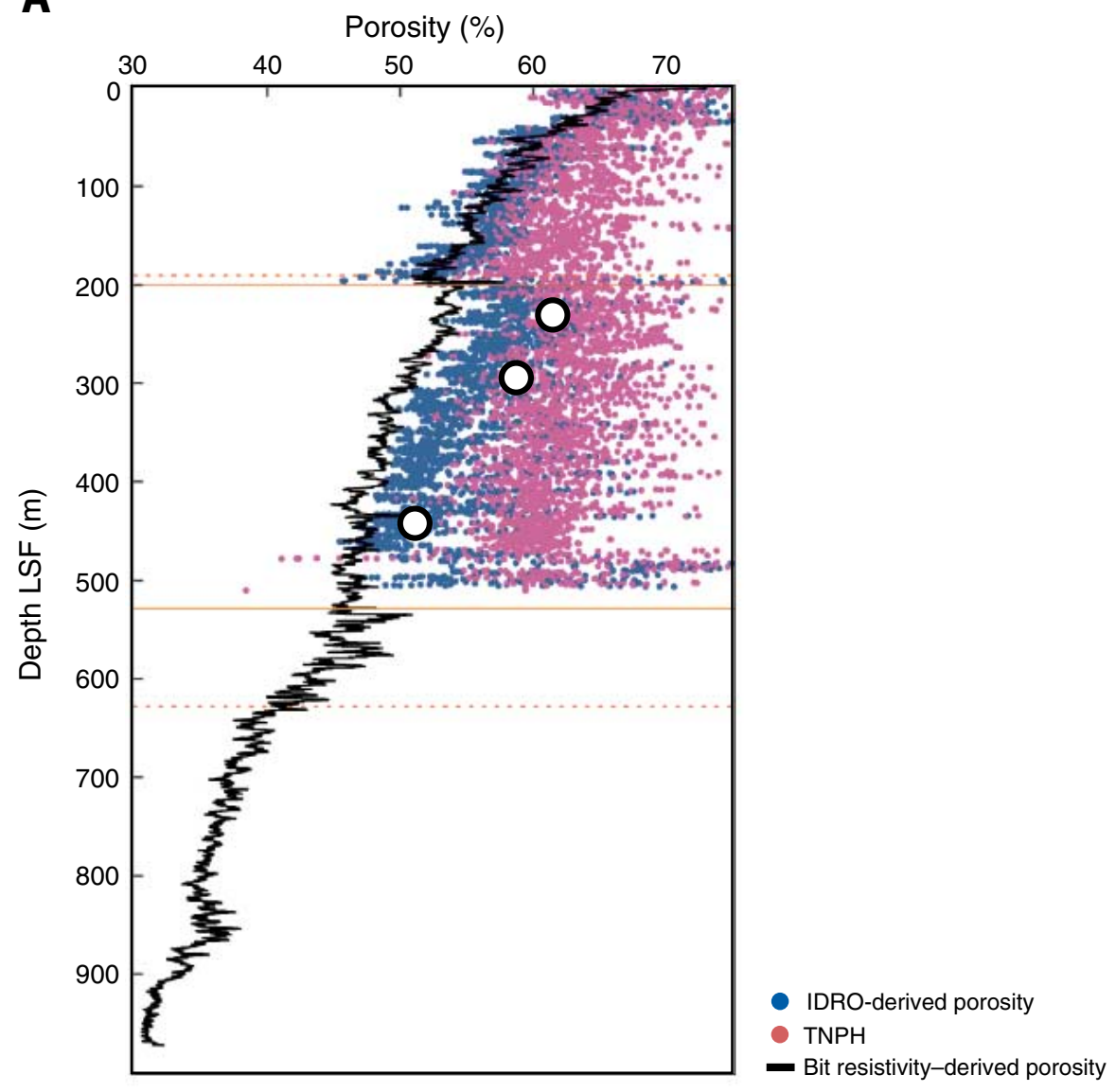


Figure F3 (continued). B. Bit and ring resistivity-derived porosity using Archie's law with parameters $a=1$ and $m=2.4$ in Hole C0006B.

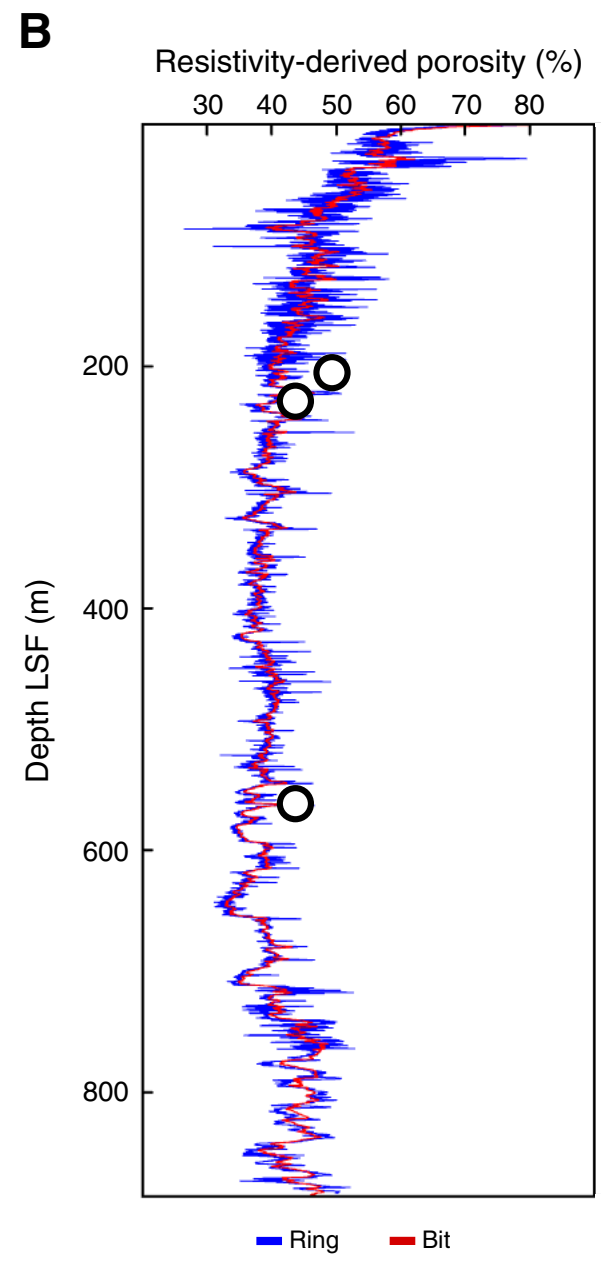


Figure F4. Diagram of experimental setup for Site C0001 and C0006 permeability samples. The specimen (Sp) is inserted in a jacket clamped on end pieces. Confining pressure $\left(P_{\mathrm{C}}\right)$, upstream $\left(P_{\text {up }}\right)$ and downstream $\left(P_{\text {down }}\right)$ pore fluid pressure, and circuits are indicated by solid lines.

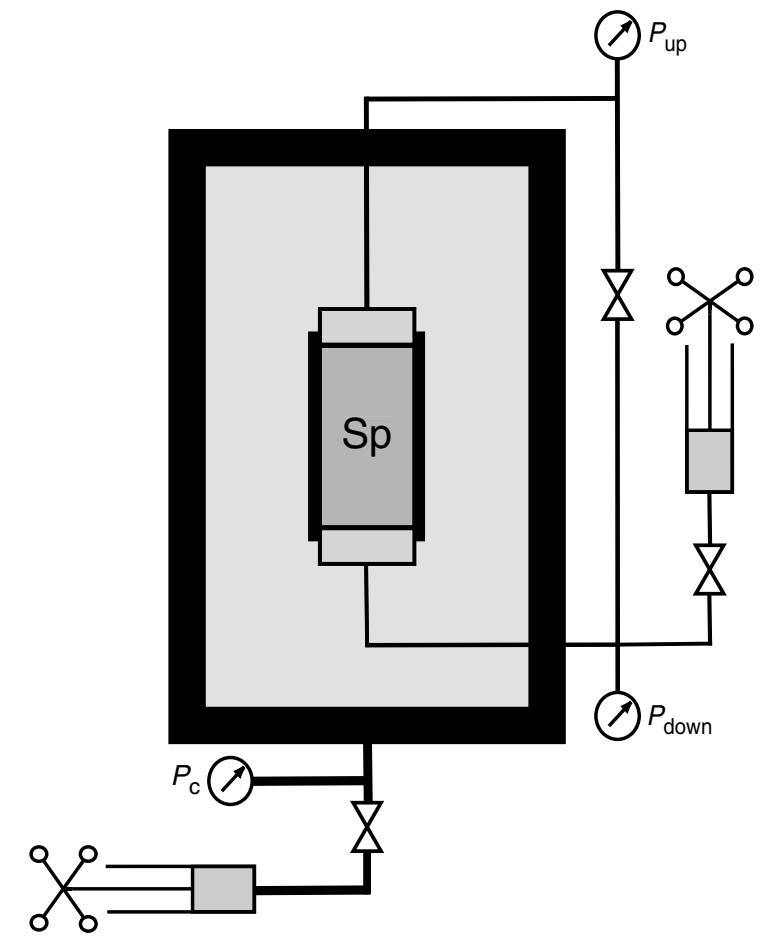


Figure F5. Example plot of pore fluid pressure evolution during a permeability test using the pulse decay method. Test was run on a sample from Section 315-C0001F-18H-6 at $30 \mathrm{MPa}$ effective pressure. A. Curves corresponding to the evolution of pore pressure at both ends of the sample. $P_{\text {down }}=$ downstream pore fluid pressure, $P_{\text {up }}=$ upstream pore fluid pressure. (Continued on next page.)

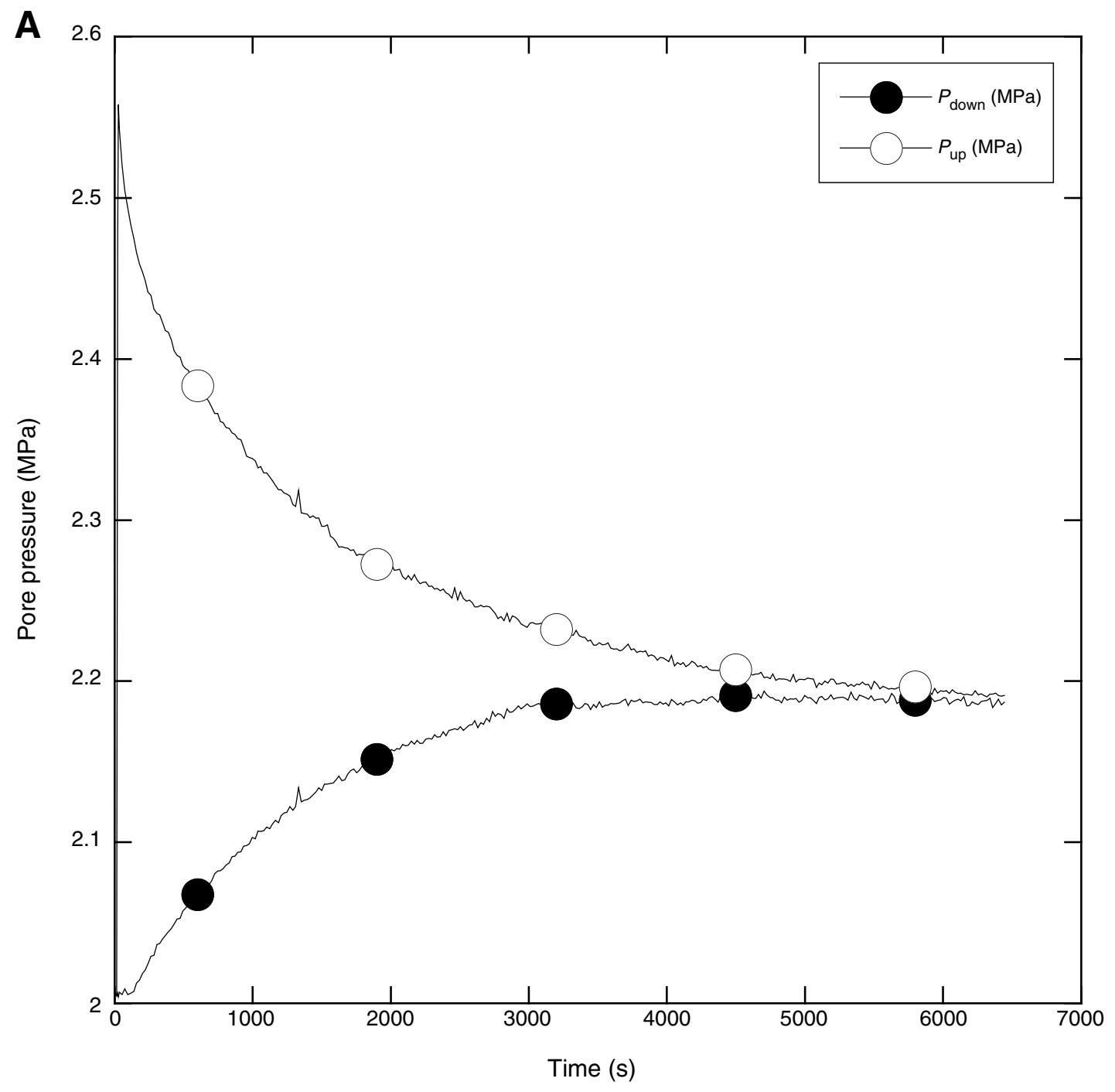


Figure F5 (continued). B. Differential pore pressure following an exponential decay law leading to a permeability of $6.22 \times 10^{-20} \mathrm{~m}^{2}$.

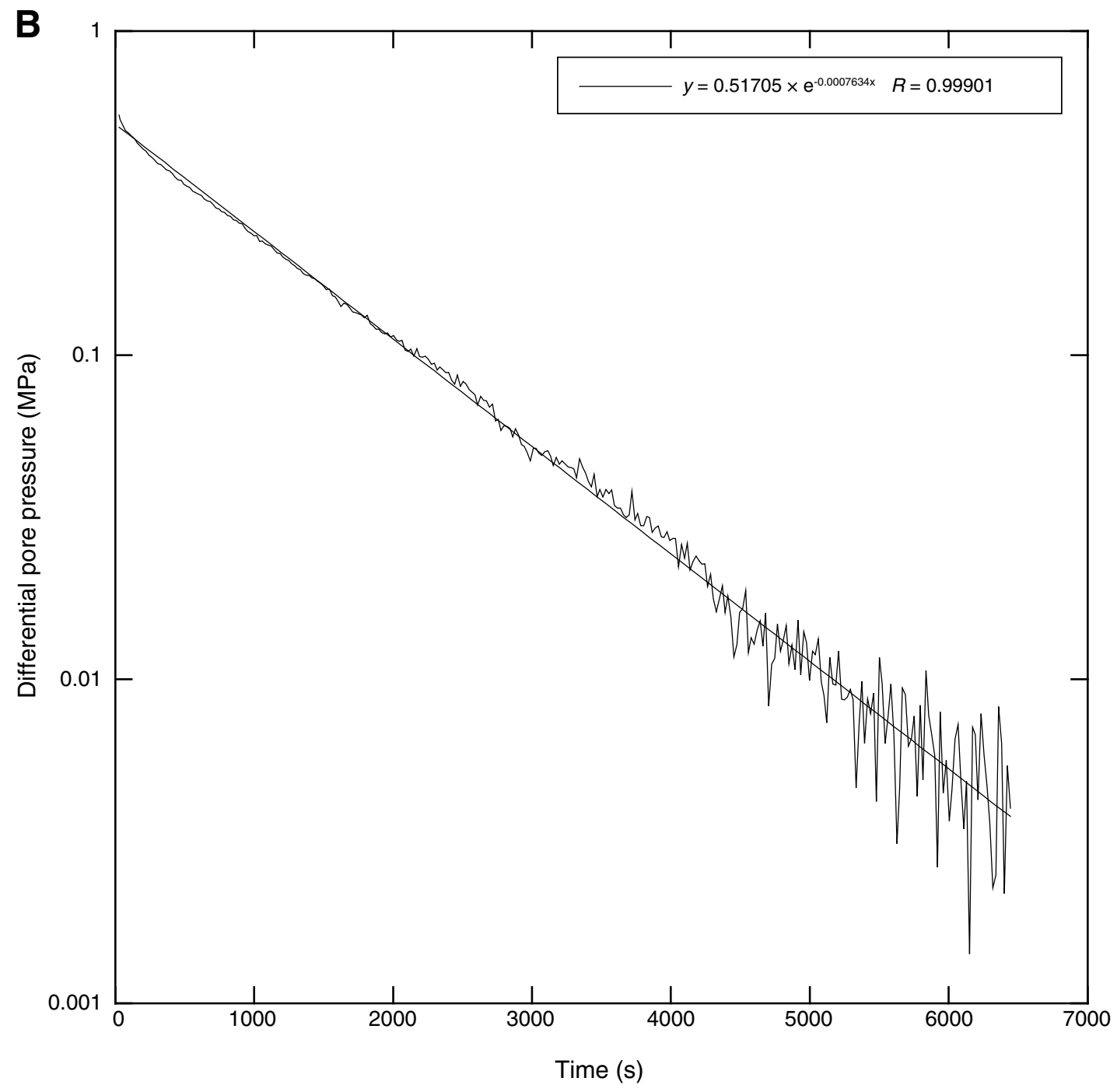


Figure F6. Plot of permeability data at initial pressure conditions $\left(P_{\mathrm{C}}=3 \mathrm{MPa}\right.$ and $\left.P_{\mathrm{P}}=2 \mathrm{MPa}\right)$ as a function of depth, Sites C0001 and C0006.

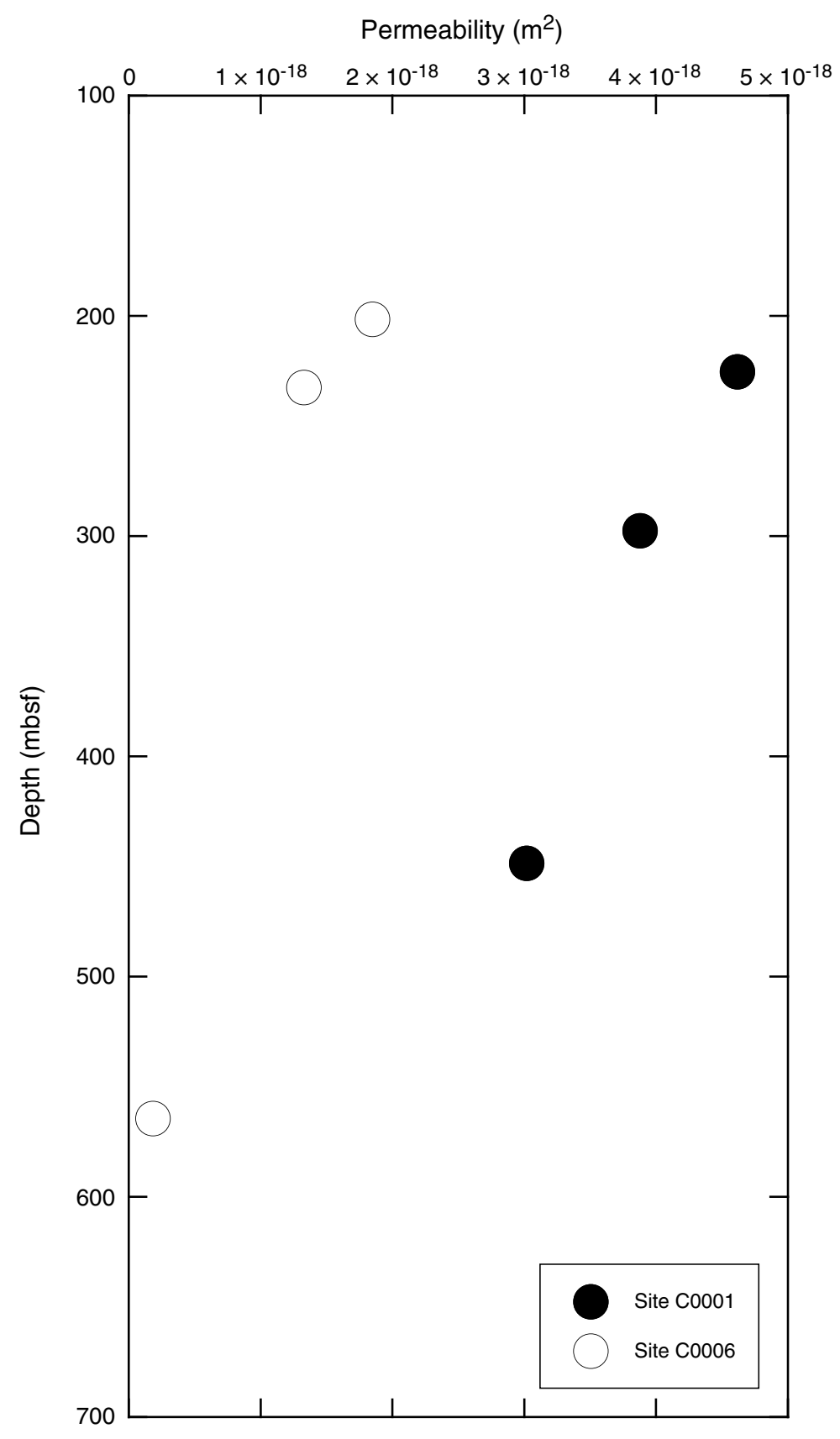


Figure F7. Plot of permeability at initial pressure conditions $\left(P_{\mathrm{C}}=3 \mathrm{MPa}\right.$ and $\left.P_{\mathrm{P}}=2 \mathrm{MPa}\right)$ versus porosity (unstressed state) data for all tested samples, Sites C0001 and C0006.

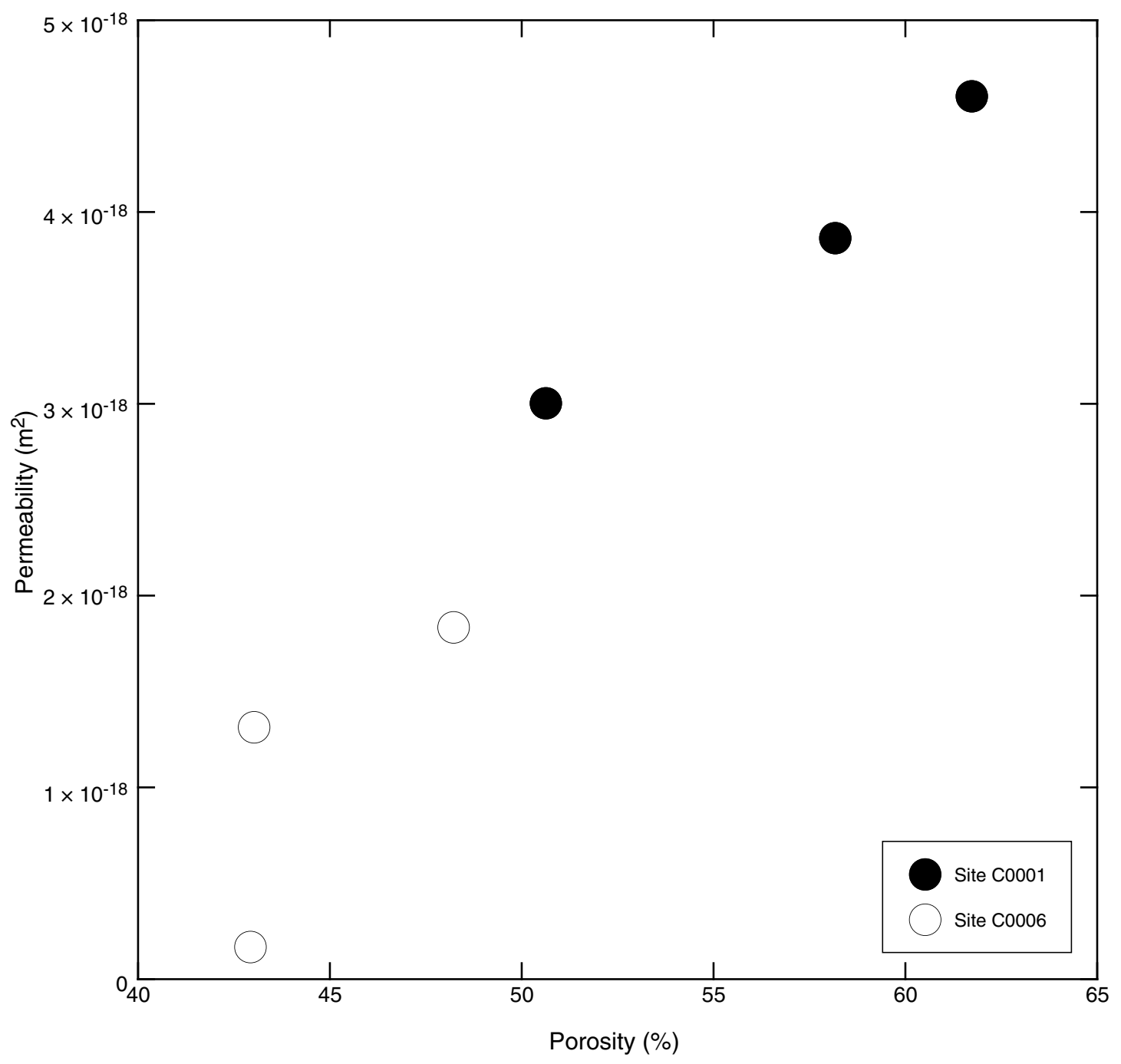


Figure F8. Plots of permeability data as a function of effective confining pressure. A. Site C0001. (Continued on next page.)

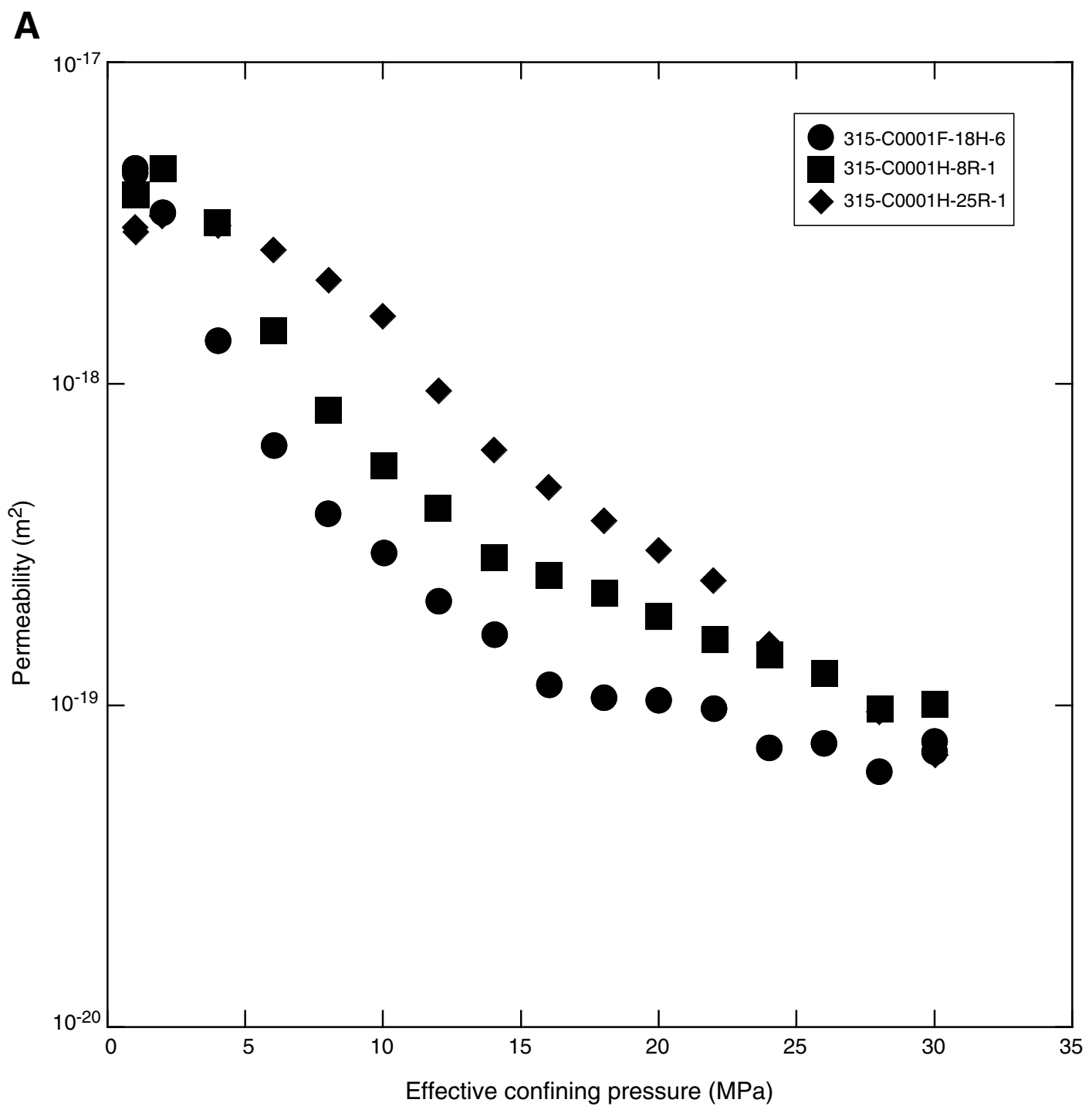


Figure F8 (continued). B. Site C0006.

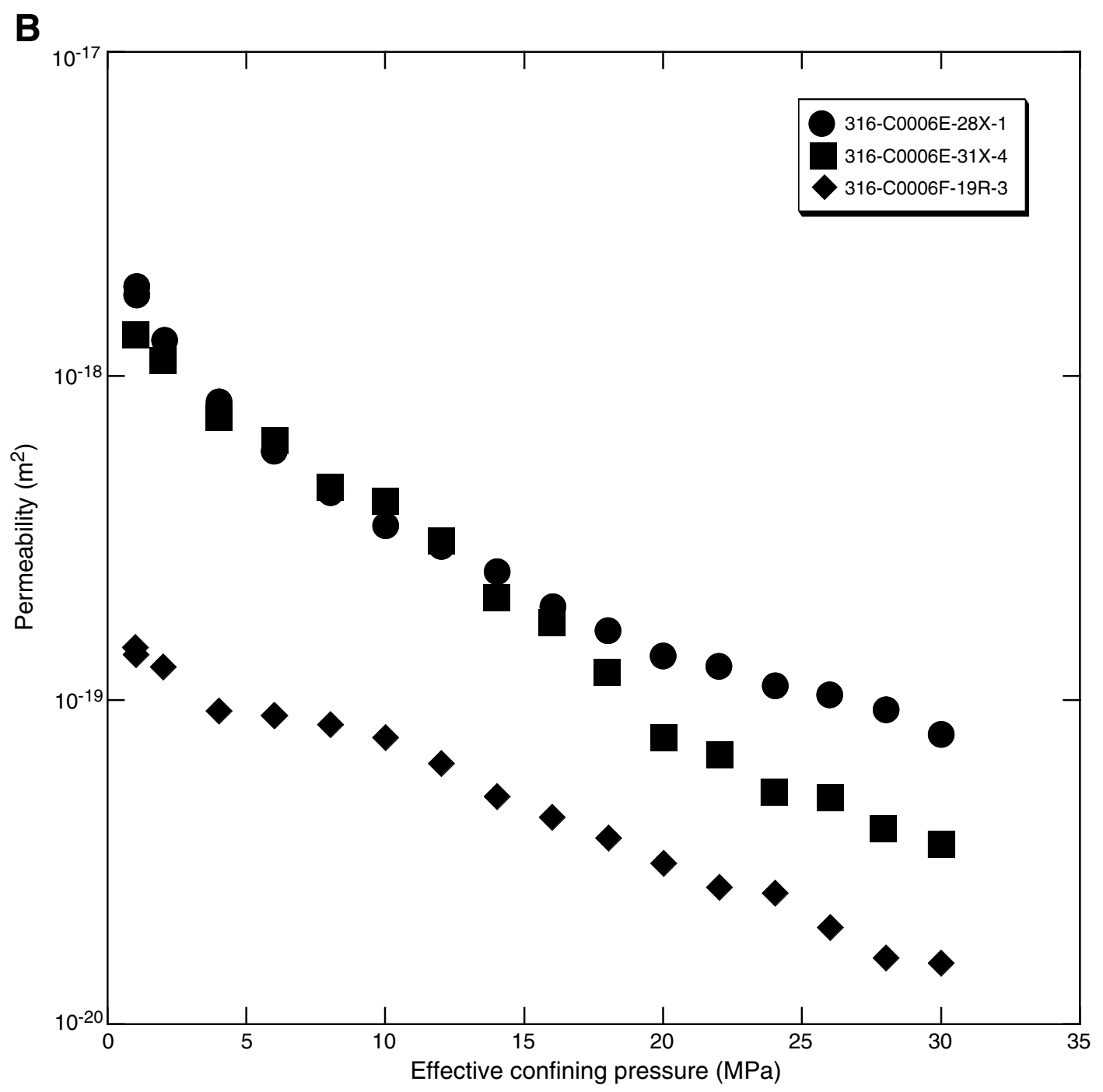


Table T1. Porosity data for tested samples as a function of depth, Sites C0001 and C0006.

\begin{tabular}{lcc}
\hline Hole, core, section & $\begin{array}{c}\text { Depth } \\
\text { (mbsf) }\end{array}$ & $\begin{array}{c}\text { Porosity } \\
(\%)\end{array}$ \\
\hline $315-$ & & \\
C0001F-18H-6 & 225 & 61.7 \\
C0001H-8R-1 & 297 & 58.2 \\
C0001H-25R-1 & 448 & 50.6 \\
316- & & \\
C0006E-28X-1 & 201 & 48.2 \\
C0006E-31X-4 & 232 & 43.0 \\
C0006F-19R-3 & 564 & 42.9 \\
\hline
\end{tabular}

